ELORE (ISSN 1456-3010), vol. $18-1 / 2011$.

Julkaisija: Suomen Kansantietouden Tutkijain Seura ry.

[http://www.elore.fi/arkisto/1_11/kirjat_mahlamaki.pdf]

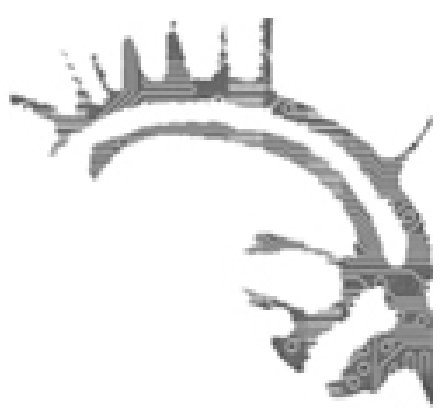

\title{
KIRJA-ARVIO
}

\section{Avaimia ARKistojen AARTEISIIN}

HYT'TINEN, ELSI \& KIVILAAKSO, KATRI (toim.) 2010: Lukemattomat sivut. Kirjallisuuden arkistot käytössä. Helsinki: SKS. 231 sivua.

\section{Tiina Mahlamäki}

Elsi Hyttisen ja Katri Kivilaakson toimittama teos Lukemattomat sivut tarkastelee kirjallisuuden arkistoja, arkistoaineistojen tarjoamia mahdollisuuksia ja rajoituksia sekä arkistoja ja arkistointia tutkimuksenteon kehyksinä. Teoksen avaava artikkeli on viisas ja kaunopuheinen johdatus siihen, mitä kaikkea arkistolla voidaan tarkoittaa, niistä prosesseista joiden myötä arkistot muodostuvat sekä erityisesti siitä, minkälaisten valtasuhteiden lävistämiä arkistot aina ja välttämättä ovat. Tekstin luettuaan (viimeistään) ymmärtää, etteivät arkistot koskaan ole viattomia menneisyydessä syntyneiden asiakirjojen säilytyspaikkoja.

Sekä kiehtovana että turhauttavana voidaan pitää sitä tosiasiaa, että arkistot ovat aina keskeneräisiä, puutteellisia ja epäjohdonmukaisia. Tämä koskee erityisesti henkilöarkistoja. Yhden henkilön elämää koskeva aineisto ei koskaan löydy yhdestä paikasta, vaan se on hajautuneena erilaisiin muistiorganisaatioihin, ja kaikkea ei tietenkään ole arkistoitu ollenkaan. Arkistoidut asiakirjat saattavat olla vahingoittuneita, päiväämättömiä, epäselviä. Aineistojen sisällöt voivat olla myös keskenään ristiriitaisia, joskus harhaanjohtavia ja usein monitulkintaisia. Aina tutkijan mieliharmiksi jää vastaamattomia kysymyksiä, solmimattomia langanpäitä. Tämä teos kertoo muutamista ongelmien ratkaisuyrityksistä, langanpäiden solmimisista ja erilaisista mahdollisuuksista arkistoaineistojen äärellä.

\section{UNOHDETUT KIRJAILIJATTARET}

Feministisen kirjallisuudentutkimuksen agendaan on kuulunut etsiä unohdettuja naisia ja nostaa heitä kanonisoitujen miesten rinnalle ja mielellään ohikin. Tämä näkökanta 
ei ole enää vallitseva, vaan unohdettuja tai oikeastaan marginaaliin jääneitä kirjailijoita tarkastellaan osana omaa aikaansa ja kirjallisuudesta käytäviä kulttuurisia kamppailuja ja keskusteluja. Ongelmana tutkijalle usein on se, miten ylipäätään löytää aineistoa marginaaliin jätetyistä tai jättäytyneistä kirjailijoista. Näitä ongelmia pohtii Elsi Hyttinen artikkelissaan työväenkirjailija Elvira Willmanista, jonka elämästä on jäänyt vain harvoja ja fragmentaarisia jälkiä. Viranomaisten arkistoihin meistä kaikista jää jälkiä, ja Willmanin tapauksessa jälkiä löytyy myös Etsivän Keskusrikospoliisin arkistoista olihan hän punaisten puolella taistellut ja Neuvostoliittoon paennut poliittinen aktiivi. Vasta Neuvostoliiton kaaduttua oli mahdollista löytää varma tieto myös Willmanin kuolemasta, mikä mahdollisti kirjailijattaren tarinan loppuun kirjoittamisen. Hyttisen artikkelista käy ilmi, että vasta Willmanin julkaisemattomiin teoksiin tutustuminen tarjoaa mahdollisuuden tarkastella kirjailijan tuotantoa kokonaisena, ja esiin piirtyvä kuva näyttää hyvin erilaiselta kuin aiempi, vain julkaistuihin näytelmiin perustunut kuva.

Kirjallisuushistorioiden unohtamaa kirjailijaa käsittelee myös Suvi Ratinen artikkelissaan "Huoneen hengettären lumo". Hän tarkastelee Ain'Elisabet Pennasen jäämistöstä löytynyttä käsikirjoitusta nimeltä "Karadja Nikolajevna" suhteessa Pennasen julkaistuun tuotantoon kohdistaen katseensa erityisesti naisen ja kodin suhteeseen. Kuten Willmanin myös Pennasen kohdalla vasta julkaisemattomiin töihin tutustuminen antaa mahdollisuuden arvioida kirjailijan tuotantoa kokonaisuudessaan. Vastaamattomaksi kysymykseksi jää, miksi huolellisesti rakennettu ja viimeistelty teos on jäänyt julkaisematta sekä kirjoitusaikanaan että kirjailijan pojan, Jarno Pennasen, kootessa äitinsä jäämistöstä postuumeja julkaisuja.

\section{KIRJOITTAMISEN ARKEOLOGIAA}

Arkistotutkijan tarkan silmän alle voi päätyä jopa käärepaperiliuska muistiinpanoineen, kuten Hanna Karhun artikkelissa, jossa rekonstruoidaan Otto Mannisen runon syntyprosessia. Artikkeli edustaa geneettistä tutkimusta, jossa kirjoitus ymmärretään prosessimaiseksi ja jossa tarkastellaan teoksen syntyvaiheita valottavia käsikirjoituksia. Niiden avulla voidaan pohtia itse kirjoitusprosessia sekä niitä erilaisia mahdollisuuksia, jotka julkaistussa teoksessa jäivät toteutumatta. Artikkeli osoittaa yhtäältä, miten Otto Mannisen roolit suomentajana ja runoilijana olivat toisiinsa elimellisesti kietoutuneita ja toisaalta, miten yksittäinen dokumentti voi paljastaa tutkimuskohteestaan uusia, kiehtovia ja kiinnostavia seikkoja. Tässä myös uudet tulkintanäkökulmat tuovat uutta valoa jo aiemmin tarkastelun kohteena olevaan dokumenttiin.

Kirjoittamiseen prosessina keskittyy myös Minna Maijala selvitellessään Minna Canthin näytelmien rakentumista ja viimeistelyä. Hän tuo uuteen valoon Canthin ja teatterinjohtaja Kaarlo Bergbomin suhteen, joka aiemmin on märitelty oppilasmentori-suhteeksi, ja Bergbomin on tulkittu vaikuttaneen huomattavassa määrin Canthin näytelmiin. Maijalan tarkastelema kirjeenvaihto osoittaa kuitenkin Canthin suhtautuneen hyvinkin kriittisesti teatterinjohtajan ehdotuksiin ja ohjausyrityksiin. Hän piti pääosin kiinni omista näkemyksistään, vaikka välit vaikutusvaltaiseen ohjaajaan rikkoutuivatkin. 
Teatterinjohtajalla on näytelmäkirjoittajaan nähden paljon valtaa, ja sama jännite koskee kirjailijan ja kustantajan välistä suhdetta. Kukku Melkas ottaa tarkastelunsa kohteeksi kirjailija Maila Talvion sekä kustannusjohtajien Werner Söderströmin ja Jalmari Jäntin välisen, miltei puoli vuosisataa jatkuneen kirjeenvaihdon. Viime vuosisadan alun kirjallisella kentällä arkaluontoisia ja moraalisesti kyseenalaisia aiheita ei voinut vapaasti käsitellä, vaan niistä oli huolellisesti neuvoteltava kustantajan kanssa. Ensimmäiset parikymmentä vuotta kustantajat osoittavat kirjeensä professorinrouva Mikkolalle; vasta vuonna 1912 häntä aletaan nimittää kirjailijaksi. Muutoinkin kirjeenvaihto osoittaa Maila Talvion käsityksen omasta merkityksestään suomalaisen kirjallisuuden kentällä muuttuvan vuosikymmenien saatossa; aroista tiedusteluista ja pyynnöistä siirrytään kohti virallisempaa sopimuspuhetta ja tulevista teoksista tiedottamista. Valtasuhde muuttuu kirjeenvaihdon myötä ja nuorelle maisteri Jalmari Jäntille osoitetut kirjeet ovat paikoin hyvin käskeviä.

\section{TEOKSEN, TEKIJYYDEN JA JULKAISEMISEN PROBLEMATIIKKAA}

Siinä missä Maila Talvio saattaa kirjeissään kustantajalle valitella yksityiselämänsä ongelmia, käsittelee Algot Untola kirjeenvaihdossaan yksinomaan kustantamiseen ja julkaisemiseen liittyviä asioita. Yksityiselämänsä hän pitää yksityisenä. Hän ei edes allekirjoittanut kirjeitään omalla nimellään vaan käytti jotain lukuisista tekijänimistään, kuten Maiju Lassila tai Irmari Rantamala. Kirjeenvaihto on Untolalle tekijyyden ja tuotannon pohtimista. Kaisa Kurikka joutuukin kiperien ongelmien eteen Untolan kirjeenvaihtokokoelmaa ja käsikirjoituspinoa tarkastellessaan: "Käsikirjoitussäkki ja kirjekasa ovat teoreettisesti ja metodologisesti, elleivät peräti ontologisestikin, haastavia tekijyyden tutkijalle, sillä ne saavat pohtimaan lukutapoja sekä tutkimusmenetelmiä ja jopa perustavaa kysymystä: mikä tekijä on?” (s. 117.) Kurikan artikkeli laajenee Untolan käsittelystä tarkastelemaan mielenkiintoisella tavalla tekijyyden, tuotannon ja ilmaisun käsitteitä - ja tarjoaa lopussa kirjallisen vastakohdan Untolan ylitsepursuavalle kirjoittamiselle: kirjoittamasta kieltäytyvät kirjailijat, jotka vastaavat kaikkeen "mieluummin ei."

Ei-kirjoittamisen problematiikkaa sivuaa myös Katri Kivilaakson artikkeli, jossa hän pohtii Elina Vaaran julkaisemattomiksi ja osin kirjoittamattomiksikin jääneitä muistelmia. Vaara ei saanut koskaan muistelmiaan valmiiksi, ja valmistuneiden tekstien punainen lanka käsitteli nimenomaan muistelemisen vaikeutta. Sinikantisissa muistivihoissa Vaaran teksti vaihtelee päiväkirjoista elämäkerrallisiin teksteihin ja muistelmiin sekä kirjeisiin jo edesmenneille ystäville. Vaaran julkaisua varten kirjoittamat muistelmat ja päiväkirjamaiset merkinnät vertautuvat Anna-Maija Tallgrenin nuoruuden päiväkirjaan muutamasta rakkauden päivästä Pariisissa, johon Anna Kuismin artikkelissaan syventyy. Tallgren rakentaa päiväkirjansa huolellisesti kuin julkaisua varten, mutta aiheen arkaluontoisuuden - naimattoman naisen rakkaussuhde naimisissa olevaan mieheen - vuoksi teosta olisi 1900-luvun ensimmäisellä vuosikymmenellä ollut mahdoton julkaista ilman häväistystä. Niin Tallgren kuin Vaara tasapainoilevat sen välillä, mitä ja miten he haluavat muistaa ja mitä on ylipäätään mahdollista julkaista. 


\section{VALTA JA ETIIKKA ARKISTOTUTKIMUKSESSA}

Elina Vaara on omia muistelmiaan kirjoittaessaan tietoinen "muistelijan vallasta muistaa ja selittää asiat jälkeenpäin niin kuin oikeaksi katsoo" (s. 145). Ja valtaan - niin muistelijan kuin tutkijan - liittyy aina myös vastuu. Vaaraa käsittelevän artikkelinsa lopussa Kivilaakso tarkasteleekin lyhyesti niitä eettisiä ongelmia, joihin elämäkerran kirjoittajien olisi vastattava. Arkistoaineistoja ei arkistojen sääntöjen mukaan saa käyttää niitä luovuttaneiden tai heidän läheistensä vahingoittamiseksi tai halventamiseksi. Mutta mikä on minäkin ajankohtana, kenelle ja mistä näkökulmasta vahingoittavaa ja halveksintaa? Eettistä ei ole sekään, että aineistosta löytyvät ristiriitaisuudet silotellaan pois. Myös Elsi Hyttinen korostaa, että " $[t]$ oisen elämästä kirjoittaminen asettaa aina myös eettisen ongelman" (s. 34). Eettisiin kysymyksiin ei ole olemassa yksiselitteistä ratkaisua, mutta vastuu tulkinnoista on aina tutkijalla itsellään. Arkistot eivät tarjoa muuta kuin loputtomia viitteitä ja jälkiä, joita tutkija omista lähtökohdistaan käsin seuraa tai jättää seuraamatta. Tutkija ei voi koskaan tietää, miten lähellä tai kaukana hänen rakentamansa tarina on aidosti tapahtunutta todellisuutta. Historiallisen totuuden saavuttaminen on tietenkin mahdotonta, mutta tutkijalle keskeistä on itse matka kohti sitä, tavoittelemisen prosessi.

\section{KirjailijahaAStatTElut}

Kirjallisuusarkiston kirjailijahaastattelut muodostavat massiivisen kokoelman, johon on koottu hyvinkin pitkiä ja yksityiskohtaisia suomalaisten kirjailijoiden "elämä ja teokset" -tyyppisiä haastatteluja. Kokoelman pääosa koottiin Ritva Haavikon johtamassa Suomen Akatemian projektissa, joka suunniteltiin ja toteutettiin aikana, jolloin myös folkloristiikassa ja uskontotieteessä vannottiin laajojen haastattelukokonaisuuksien nimiin. Mikä estäisi lähestymästä kirjailijahaastattelujakin kulttuurin- ja perinteentutkimuksen välinein? Vaikka haastattelut on pyritty rakentamaan standardimallin mukaisesti yli 600 kysymyksen voimin, jokainen vastaaja suhtautui kysymyksiin ja listaan omalla tavallaan, myötäillen tai vastustaen, avautuen tai väistellen, rakentaen omaa kertomustaan itsestään kirjailijana. Haastateltavathan olivat hyvin tietoisia haastattelujen tulevasta käytöstä tutkimusaineistona.

Katri Kivilaakso ja Suvi Ratinen hahmottavat artikkelissaan "Tekijän ääni” kirjailijahaastattelujen taustaa, merkitystä ja hyödyntämistä kirjallisuudentutkimuksessa. Haastatteluja ei koskaan käytetty siinä mitassa kuin oli tarkoitus ja 1980-luvulta lähtien niiden suosio hiipui. Kirjoittajat näkevät tutkimusta varten tehdyt haastattelut kuitenkin kirjallisuudentutkimuksen kannalta kiinnostavaksi. Vaikka tekijän kuolemaa on pitkään hehkutettu, on kirjailijalla kuitenkin ainakin oman tuotantonsa suhteen asiantuntijuutta, jota ei muualta löydä, ja jota tutkijoidenkin kannattaisi hyödyntää. Tätä pyrkii Kivilaakso tekemään haastatellessaan kirjailija Pirkko Saisiota. Hän avaa artikkelissa haastattelutilanteita ja niiden rakentumista, suhteuttaa kokemuksensa aiempiin kirjailijahaastatteluihin samalla kyseenalaistaen niitä. Pirkko Saisio on teoksissaan käyttänyt eri tekijänimiä ja myös problematisoinut omaelämäkerrallisuutta. Kun 
kirjailijahaastatteluprojektissa oletettiin haastattelijan ja haastateltavan välille rakentuvan vuorovaikutussuhteen ja luotettiin kirjailijan muistiin, muistikuviin ja kerrontaan, Saisio kyseenalaistaa tämän huomauttamalla, että on esimerkiksi mahdotonta muistaa, mitä on aikaisempien teostensa kirjoittamishetkellä ajatellut. Luotettavana, autenttisena kertomuksena siitä, mitä kirjailijan elämässä on tapahtunut, kirjailijahaastatteluja ei voida pitää. Ne toistavat sitä näkemystä, jonka kirjailija on haastattelutilanteessa halunnut itsestään kertoa.

Kirjailijahaastattelut tarjoavat kuitenkin monenlaisia käyttömahdollisuuksia. Kivilaakso ja Ratinen ehdottavat vaikkapa haastattelujen käyttöä poikkileikkauksena tietyn aikakauden kirjallisuus-, kirjailija- ja kritiikkikäsityksistä tai kustantajasuhteista. Strukturoidut haastattelut tarjoavat lukemattomia mahdollisuuksia tämänkaltaiseen käyttöön. Samojen kysymysten esittäminen kaikille kirjailijoille tarjoaa myös mahdollisuuden tarkastella niitä eroavaisuuksia, joilla kirjailijat näihin kysymyksiin vastasivat, tai jättivät vastaamatta. Hedelmällisintä on tarkastella haastatteluja muistitietona, jolloin vastausten subjektiivisuus, ristiriitaisuus, aukkoisuus tai "väärin" muistaminen ja epäluotettavuus eivät ole ongelmia vaan muistitiedon ominaisuuksia. Artikkelin kirjoittajat haastavatkin haastattelujen jatkamiseen, mutta laajemmalla kentällä. Kulttuurintutkijan näkökulmasta on käsittämätöntä, että haastatteluista on tullut kirjallisuudentutkimuksessa marginaalinen aineistoryhmä.

Dosentti Tiina Mahlamäki työskentelee uskontotieteen yliopisto-opettajana Turun yliopiston historian, kulttuurin ja taiteiden tutkimuksen laitoksella. 